\title{
Risk factors for trauma-induced coagulopathy- and transfusion-associated multiple organ failure in severely injured trauma patients
}

\author{
Kirsten Balvers ${ }^{1,2}$, Mathijs R. Wirtz ${ }^{1,2}$, Susan van Dieren ${ }^{3}$, J. Carel Goslings ${ }^{1}$ and Nicole P. Juffermans ${ }^{2}$ \\ 1 Trauma Unit, Department of Surgery, Academic Medical Center, Amsterdam, Netherlands \\ 2 Department of Intensive Care, Academic Medical Center, Amsterdam, Netherlands \\ ${ }^{3}$ Clinical Research Unit, Academic Medical Center, Amsterdam, Netherlands
}

\section{Edited by:}

Takashi Tagami, Nippon Medical

School, Japan

\section{Reviewed by:}

Tamas Szakmany, Cardiff University, UK

Hideo Yasunaga, The University of Tokyo, Japan

\section{${ }^{*}$ Correspondence:}

Nicole P. Juffermans, Department of Intensive Care Medicine, Academic Medical Center, Meibergdreef 9, Amsterdam 1105 AZ, Netherlands e-mail: n.p.juffermans@amc.uva.nl
Background: Both trauma-induced coagulopathy (TIC) and transfusion strategies influence early outcome in hemorrhagic trauma patients. Their impact on late outcome is less well characterized. This study systematically reviews risk factors for TIC- and transfusion-associated multiple organ failure (MOF) in severely injured trauma patients.

Materials and methods: A systematic search was conducted in PubMed and Embase. Studies published from 1986 to 2013 on adult trauma patients with an injury severity score $\geq 16$, investigating $\mathrm{TIC}$ or transfusion strategies with MOF as primary or secondary outcome, were eligible for inclusion. Results of the included studies were evaluated with meta-analyses of pooled data.

Results: In total, 50 studies were included with a total sample size of 63,586 patients. Due to heterogeneity of the study populations and outcome measures, results from 7 studies allowed for pooling of data. Risk factors for TIC-associated MOF were hypocoagulopathy, hemorrhagic shock, activated protein $\mathrm{C}$, increased histone levels, and increased levels of markers of fibrinolysis on admission. After at least $24 \mathrm{~h}$ after admission, the occurrence of thromboembolic events was associated with MOF. Risk factors for transfusion-associated MOF were the administration of fluids and red blood cell units within $24 \mathrm{~h}$ post-injury, the age of red blood cells ( $>14$ days) and a ratio of FFP:RBC $\geq 1: 1$ (OR 1.11, 95\% Cl 1.04-1.19).

Conclusion: Risk factors for TIC-associated MOF in severely injured trauma patients are early hypocoagulopathy and hemorrhagic shock, while a hypercoagulable state with the occurrence of thromboembolic events later in the course of trauma predisposes to MOF. Risk factors for transfusion-associated MOF include administration of crystalloids and red blood cells and a prolonged storage time of red blood cells. Future prospective studies investigating TIC- and transfusion-associated risk factors on late outcome are required.

Keywords: trauma, multiple organ failure, transfusion, coagulopathy, resuscitation

\section{INTRODUCTION}

Despite advances in trauma care, multiple organ failure (MOF) still remains one of the leading causes of late mortality (occurring after more than 3 days) in trauma patients $(1,2)$. The incidence of MOF in severely injured trauma patients ranges from $15 \%$ up until $40 \%(3-6)$, with an associated mortality rate that varies between $24 \%$ (3) and $51 \%$ (6). Even though MOF-related mortality has been shown to decrease over the last decades $(2,6)$, mortality is still 10 times higher in patients with MOF compared to patients without MOF $(4,5)$.

Over the last decade, trauma-induced coagulopathy (TIC) is increasingly recognized to contribute to adverse early outcome

Abbreviations: ED, emergency department; FFP, fresh frozen plasma; ISS, injury severity score; MOF, multiple organ failure; RBC, red blood cell; RCT, randomized controlled trial; rVII, recombinant factor VII; TIC, trauma-induced coagulopathy. in trauma patients (7-13). In recognition of that, transfusion strategies have changed toward more and earlier administration of plasma. This has led to a shift in the ratio of RBC:FFP to 1:1. Furthermore, fluid resuscitation with crystalloids has evolved from aggressive therapy to a minimal amount of crystalloid administration. More and earlier administration of plasma, combined with a restriction of crystalloid administration, has showed to reduce early mortality (14-16). However, the impact of both TIC and changing transfusion strategies on the occurrence of MOF has not been systematically reviewed before. Therefore, the aim of this study was to summarize risk factors for TIC- and transfusion-associated MOF in severely injured trauma patients.

\section{MATERIALS AND METHODS}

The present study was reported according to the PRISMA guidelines (preferred reporting items for systematic reviews and meta-analyses) (17). 


\section{STUDY SELECTION}

An electronic search was conducted in PubMed and Embase for articles published from 1986 to 2013. In addition, we searched for ongoing trials on www.controlled-trials.com and www.clinicaltrials.gov.

The following subject headings and free text words were used: ("Blood Coagulation Disorders"[Mesh] OR "Blood Coagulation"[Mesh] OR Coagulation[tiab] OR coagulopathy[tiab] OR "Fibrinolysis"[Mesh] OR Fibrinolysis[tiab] OR hypofibrinolysis[tiab] OR hyperfibrinolysis[tiab]) OR ("Blood Transfusion"[Mesh] OR Transfusion[tiab] OR "Transfusion Medicine"[Mesh] OR "Erythrocyte Transfusion"[Mesh] OR "Blood Component Transfusion"[Mesh]) AND ("Multiple Organ Failure"[Mesh] OR multiple organ failure ${ }^{\star}[$ tiab] OR MOF[tiab] OR (infection*[tiab] AND trauma[tiab])) AND ("Multiple Trauma"[Mesh] OR multiple trauma[tiab] OR "Wounds and Injuries"[Mesh] OR "Injury Severity Score"[Mesh] OR Injury Severity Score[tiab] OR ISS[tiab] (Table S2 in Supplementary Material).

Target population were trauma patients who suffered blunt or penetrating trauma, with a mean injury severity score (ISS) of $\geq 16$ and an age of $\geq 16$ years. Randomized controlled trials (RCTs) and observational studies investigating TIC or transfusion strategies with MOF as primary or secondary outcome were eligible for inclusion. Studies, which focused on patients with isolated traumatic brain injury or burn injury, were excluded. Both prospective and retrospective studies were included. Reviews, correspondences, case reports, expert opinions, and editorials were excluded. The search was conducted by two independent researchers (Kirsten Balvers and Mathijs R. Wirtz). Any discrepancies in the included studies were resolved by discussion between the reviewers. If necessary, an independent third reviewer was consulted. Only articles defining MOF according to the definition of the Denver (18), Marshall $(18,19)$, or SOFA (20) score were included in this review. A Denver score of more than 3 and a Marshall score of more than 5, both for at least two consecutive days, were used to define MOF. Furthermore, MOF according to the SOFA score was defined as the simultaneous failure of two or more organ systems. Organ failure was defined as a total of more than two points in a single organ. Language was limited to English, Dutch, or German. We reviewed the bibliographies of the eligible studies for citations of additional suitable studies.

\section{DATA SYNTHESIS}

Primary outcomes were risk factors for TIC- and transfusionassociated MOF. Since most of the studies in this field are observational studies, we performed a quality assessment according to the Newcastle-Ottawa Scale (21). Characteristics of the studies examined included comparability of the study groups, methods used to select study participants and determination of outcome variables. The quality of selection of patients in the included studies was rated as good if they included severely injured trauma patients and the control group was drawn from the same community as the exposed cohort. The assessment of comparability of the studies was based on the design and/or analysis used in the studies. Quality of outcome variables was determined by follow-up period and $<10 \%$ of patients lost-to-follow-up. The Cochrane Collaboration's tool for assessing the risk of bias was used to assess the quality of RCTs (22). This tool was used to evaluate RCTs on seven specific domains (sequence generation, allocation concealment, blinding of participants and personnel, blinding of outcome assessment, incomplete outcome data, selective reporting, and other sources of bias). If the results of studies were contradicting, the quality assessment was used to grade conclusions.

Review Manager (RevMan 5, The Nordic Cochrane Centre) was used to combine findings of studies in a meta-analysis. Studies were pooled if homogeneity was considered by assessing study population, intervention, and outcome. RevMan was used to determine homogeneity by the inverse variance method for a random or fixed effects model. If homogeneity was not obtained studies were excluded from meta-analysis. Heterogeneity was expressed by $I^{2}$. An $I^{2}$ of $>75 \%$ was considered as substantial heterogeneity. Meta-analysis was performed on observational studies and RCTs, in which data from observational studies and RCTs were not combined in the same meta-analysis. For the outcome of interest, risk ratios and 95\% confidence intervals were used.

\section{RESULTS}

We identified 476 articles (PubMed 320, Embase 156) meeting the inclusion criteria. Of these, seven duplicates were removed. Reviewing of the bibliographies resulted in 11 additional articles. The full texts of 114 articles were assessed for eligibility. An additional 64 reviews were excluded, bringing the total on 50 included articles with a total sample size of 63,586 patients (Figure 1). Of the 50 included studies, 46 studies were observational cohort studies and 4 were RCTs. The observational studies included 15 retrospective and 31 prospective studies. Sample size in these studies varied between 19 and 20,288 patients with a median of 384 (IQR 1351217) patients. Two studies included a heterogeneous population of intensive care patients, all other studies were restricted to trauma patients. The score of the included studies on the NewcastleOttawa scale ranged from 6 to 8 with a median of 7 . The score of the Cochrane Collaboration's tool for assessing the risk of bias ranged from 8 to 9 (Tables 1 and 2; Table S1 in Supplementary Material).

\section{RISK FACTORS FOR TIC-ASSOCIATED MOF}

Eighteen studies reported the effect of TIC on the development of MOF in trauma patients (Table 1). The presence of hypocoagulopathy on admission to the emergency department (ED) was an independent risk factor for $\operatorname{MOF}(26,30,33,35-39)$; however, studies could not be pooled due to substantial heterogeneity $\left(I^{2}=90 \%\right.$, Figure 2$)$. Hypocoagulopathy was defined by prolongation of coagulation parameters including PTT, INR, and APTT and a decreased platelet count (26). Four studies reported a decreased platelet count as an independent risk factor $(23,26$, $41,72)$. Of note, hypocoagulopathy was rare in patients without persisting shock (73). Other risk factors for TIC-associated MOF were activation of protein $\mathrm{C}$, increased levels of fibrinolytic markers (27, 36-39), and increased levels of extracellular histones (37). Of note, these risk factors were reported in small study numbers.

Taken together, after trauma, damaged endothelial cells and extracellular histones activate protein $\mathrm{C}$, which inhibits factor $\mathrm{Va}$ 


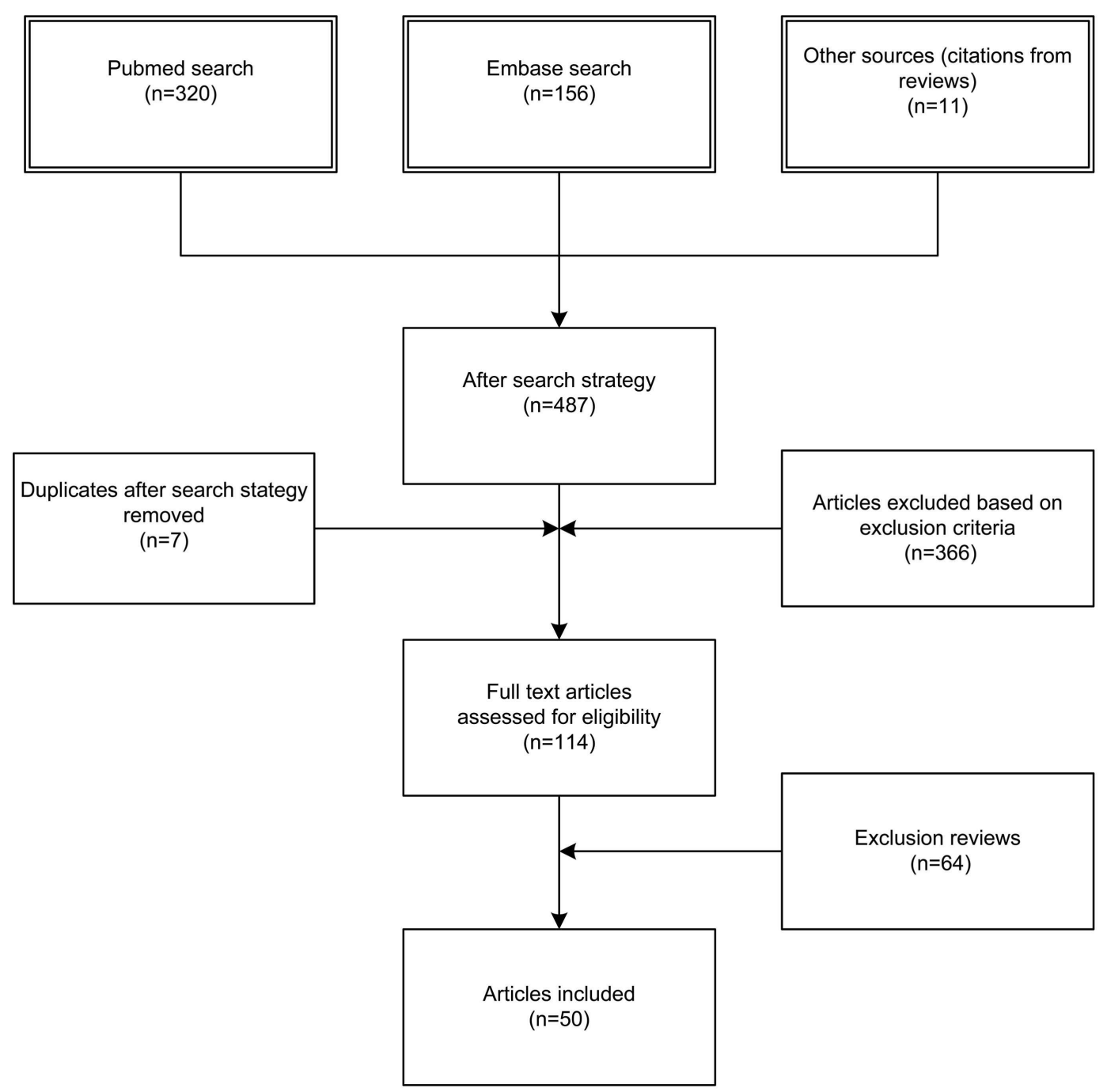

FIGURE 1 |The process of selecting studies suitable for inclusion

and VIIa and leads to hyperfibrinolysis due to the consumption of plasminogen activator inhibitor, with subsequent hypocoagulopathy $(37,74-76)$.

Later in the course of events following trauma, patients tend to develop a hypercoagulopathy as reported in 5 studies with a total of 5581 patients. In these studies, an association between thromboembolic events, including disseminated intravascular coagulation (DIC) and venous thromboembolism (VTE), and MOF was reported $(27,28,30,32,34)$. Pooling of data in a meta-analysis was not possible due to differences in outcome measures.

\section{RISK FACTORS FOR TRANSFUSION-ASSOCIATED MOF}

We found 36 studies reporting an association between transfusion and the development of MOF in trauma patients (Table 2).

\section{Fluids}

Six studies investigated the effect of the administration of crystalloids on MOF in trauma patients. The majority of studies reported crystalloid administration within the first $24 \mathrm{~h}$ post-injury as a risk factor for the development of $\operatorname{MOF}(36,42,67,69,70)$. Another study showed a trend toward a lower incidence of MOF in patients who were administered $<1000 \mathrm{ml}$ of fluids prior to arrival at the hospital. Two studies did not find a relation between fluids and MOF $(53,65)$. However, these two studies did not adjust for confounders. Pooling of data could not be performed due to difference in outcome measures. However, it is likely that crystalloid administration is an independent risk factor for MOF given that the studies, which adjusted for confounders found an association between the administration of crystalloids and MOF.

\section{Blood products}

The effect of the amount of RBCs administered on the development of MOF in trauma patients was reported in 14 studies $(5,6,36,41-43,45,46,55,56,61,66)$. There seems to be a dose-dependent association between MOF and transfusion, as a significant linear trend was found between the number of RBCs 
Table 1 | Description of included studies; risk factors for TIC-associated MOF

\begin{tabular}{|c|c|c|c|c|c|c|c|}
\hline Reference & Design & Origin & Patients & $N$ & Groups & Risk factors for MOF & Quality \\
\hline Nuytinck et al. (23) & Prospective & Europe & Trauma patients & 71 & $\begin{array}{l}\text { ARDS/MOF } \\
\text { Non-ARDS/MOF }\end{array}$ & $\begin{array}{l}\text { Plasma elastase level } \\
\text { Complement activation }\end{array}$ & $7 / 9$ \\
\hline Wudel et al. (24) & Retrospective & USA & Trauma patients & 92 & $\begin{array}{l}\text { Survivors } \\
\text { Non-survivors }\end{array}$ & No difference & $7 / 9$ \\
\hline Sigurddson et al. (25) & Prospective & Asia & Critically ill patients & 21 & $\begin{array}{l}\text { Hemorrhagic shock } \\
\text { controls }\end{array}$ & $\begin{array}{l}\text { Platelet activity and intestinal } \\
\text { platelet sequestration }\end{array}$ & $7 / 9$ \\
\hline Waydhas et al. (26) & Prospective & Europe & Trauma patients & 133 & $\begin{array}{l}\text { MOF } \\
\text { Non-MOF }\end{array}$ & $\begin{array}{l}\text { No difference in coagulopathy } \\
\text { Platelet count }<180,000 / \mu \mathrm{L}\end{array}$ & $7 / 9$ \\
\hline Gando et al. (27) & Prospective & Japan & Trauma patients & 58 & $\begin{array}{l}\text { DIC } \\
\text { Non-DIC }\end{array}$ & DIC & $6 / 9$ \\
\hline Gando et al. (28) & Prospective & Japan & Trauma patients & 47 & $\begin{array}{l}\text { DIC } \\
\text { Non-DIC }\end{array}$ & $\begin{array}{l}\text { Thrombomodulin level } \\
\text { DIC }\end{array}$ & $6 / 9$ \\
\hline Sauaia et al. (29) & Retrospective & USA & Trauma patients & 411 & $\begin{array}{l}\text { MOF } \\
\text { Non-MOF }\end{array}$ & $\begin{array}{l}\text { Colloid administration } \\
\text { Lower platelet count } \\
\text { Longer prothrombin time }\end{array}$ & $9 / 9$ \\
\hline Gando et al. (30) & Prospective & Japan & Trauma patients & 136 & $\begin{array}{l}\text { SIRS for } \leq 2 \text { days } \\
\text { SIRS for } \geq 3 \text { days } \\
\text { Non-SIRS }\end{array}$ & $\begin{array}{l}\text { SIRS } \geq 3 \text { days } \\
\text { Platelet counts } \\
\text { DIC }\end{array}$ & $6 / 9$ \\
\hline Raeburn et al. (31) & Retrospective & USA & Trauma patients & 77 & $\begin{array}{l}\text { Abdominal compartment } \\
\text { syndrome (ACS) }\end{array}$ & No difference & $7 / 9$ \\
\hline Newell et al. (32) & Retrospective & USA & Trauma patients & 1751 & $\begin{array}{l}\text { Normal } \\
\text { Overweight } \\
\text { Obese } \\
\text { Morbidly obese }\end{array}$ & VTE & $7 / 9$ \\
\hline Maegele et al. (33) & Retrospective & Europe & Trauma patients & 8724 & $\begin{array}{l}\text { Coagulopathy } \\
\text { Non-coagulopathy }\end{array}$ & Coagulopathy & $7 / 9$ \\
\hline Paffrath et al. (34) & Retrospective & Europe & Trauma patients & 7937 & $\begin{array}{l}\text { VTE } \\
\text { Non-VTE }\end{array}$ & VTE & $7 / 9$ \\
\hline Nydam et al. (35) & Retrospective & USA & Trauma patients & 1415 & $\begin{array}{l}\text { Thrombocytopenia } \\
\text { Non-thrombocytopenia }\end{array}$ & Thrombocytopenia & $8 / 9$ \\
\hline Brown et al. (36) & Prospective & USA & Trauma patients & 1877 & $\begin{array}{l}\text { Acute traumatic } \\
\text { coagulopathy } \\
\text { Non-acute traumatic } \\
\text { coagulopathy } \\
\text { Male versus female }\end{array}$ & $\begin{array}{l}\text { Activation of protein C } \\
\text { Acute coagulopathy } \\
\text { Transfusion requirements }\end{array}$ & $7 / 9$ \\
\hline Kutcher et al. (37) & Prospective & USA & Trauma patients & 132 & $\begin{array}{l}\text { High histone levels } \\
\text { Low histone levels }\end{array}$ & High histone level & $7 / 9$ \\
\hline Cohen et al. (38) & Prospective & USA & Trauma patients & 203 & - & $\begin{array}{l}\text { Higher levels of activated } \\
\text { protein } \mathrm{C} \text { upon admission }\end{array}$ & $8 / 9$ \\
\hline Cole et al. (39) & Prospective & Europe & Trauma patients & 158 & $\begin{array}{l}\text { Infection } \\
\text { Non-infection }\end{array}$ & $\begin{array}{l}\text { PC depletion of } \mathrm{PC} \text { and raised } \\
\text { PAP levels }\end{array}$ & $7 / 9$ \\
\hline Trentzsch et al. (40) & Retrospective & Europe & Trauma patients & 20,288 & $\begin{array}{l}\text { Male } \\
\text { Female }\end{array}$ & No difference in coagulopathy & $8 / 9$ \\
\hline
\end{tabular}


Table 2 | Description of included studies; risk factors for transfusion-associated MOF.

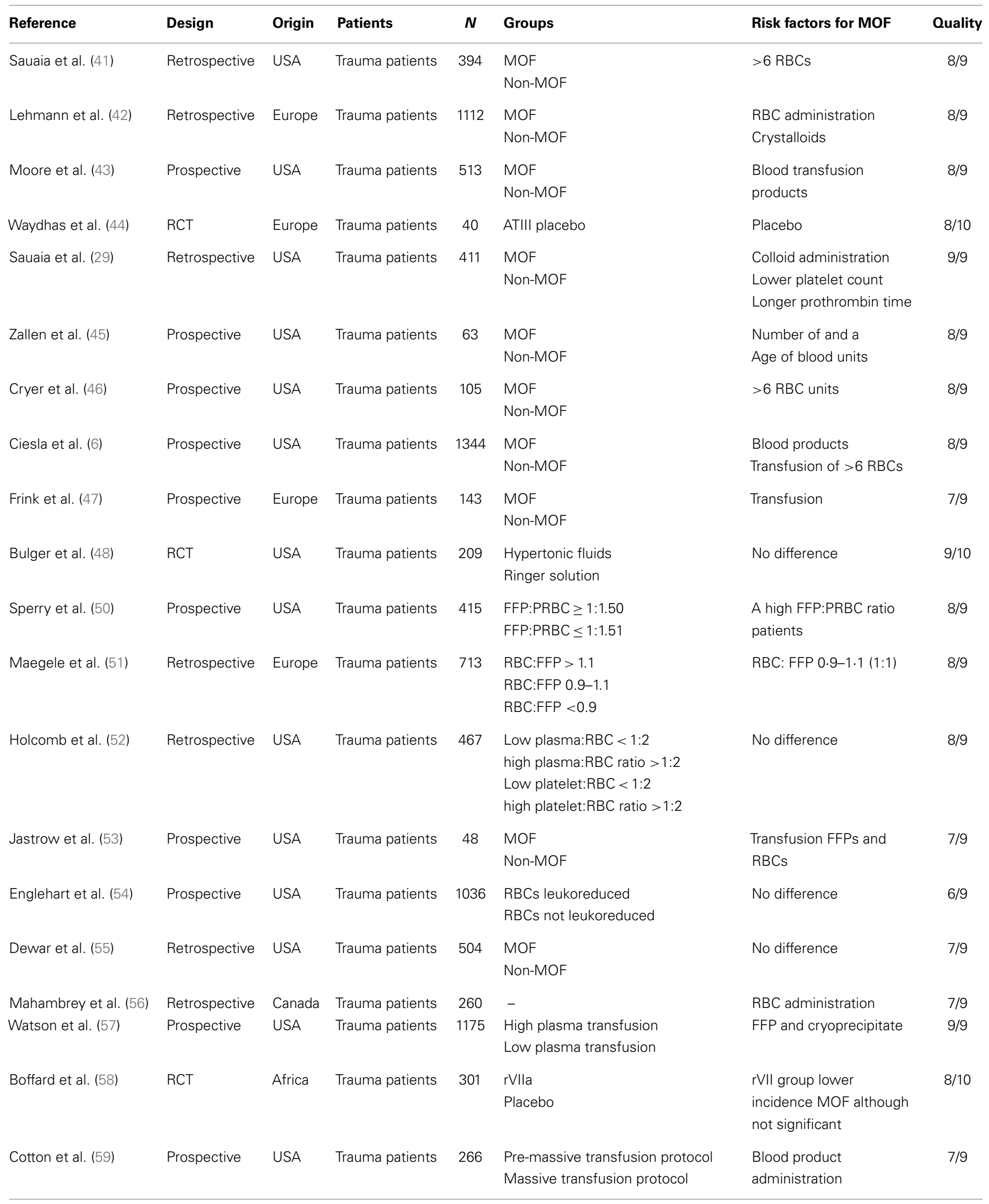


Table 2 | Continued

\begin{tabular}{|c|c|c|c|c|c|c|c|}
\hline Reference & Design & Origin & Patients & $N$ & Groups & Risk factors for MOF & Quality \\
\hline Hauser et al. (60) & $\mathrm{RCT}$ & World wide & Trauma patients & 573 & $\begin{array}{l}\text { FVIla } \\
\text { Placebo }\end{array}$ & $\begin{array}{l}\text { A trend is observed } \\
\text { toward decreased MOF } \\
\text { in rFVIla group }\end{array}$ & $9 / 10$ \\
\hline Paffrath et al. (34) & Retrospective & Europe & Trauma patients & 7937 & $\begin{array}{l}\text { VTE } \\
\text { Non-VTE }\end{array}$ & VTE & $7 / 9$ \\
\hline Brattstrom et al. (5) & Prospective & Europe & Trauma patients & 164 & - & $>10$ RBC units & $8 / 9$ \\
\hline Johnson et al. (61) & Retrospective & USA & Trauma patients & 1440 & $\begin{array}{l}\text { MOF } \\
\text { Non-MOF }\end{array}$ & $\mathrm{RBC}$ administration & $8 / 9$ \\
\hline Nienaber et al. (62) & Retrospective & Europe & Trauma patients & 36 & $\begin{array}{l}\text { FFP } \\
\text { Coagulation factor concentrates }\end{array}$ & $\begin{array}{l}\text { PCC treatment } \\
\text { associated with } \\
\text { reduction of MOF }\end{array}$ & $7 / 9$ \\
\hline Perkins et al. (63) & Retrospective & USA & Trauma patients & 369 & $\begin{array}{l}\text { Fresh whole blood } \\
\text { Apheresis platelets }\end{array}$ & No difference & $7 / 9$ \\
\hline Wafaisade et al. (64) & Retrospective & Europe & Trauma patients & 1362 & $\begin{array}{l}\text { FFP:RBC }<1: 1 \\
\text { FFP:RBC } 1: 1 \\
\text { FFP:RBC }>1: 1\end{array}$ & No difference & $7 / 9$ \\
\hline Hussmann et al. (65) & Retrospective & Europe & Trauma patients & 375 & $\begin{array}{l}<1000 \mathrm{ml} \\
1000-2000 \mathrm{ml} \\
2001-3000 \mathrm{ml} \\
>3000 \mathrm{ml}\end{array}$ & Crystalloids < 1000 ml & $7 / 9$ \\
\hline Brakenridge et al. (66) & Prospective & USA & Trauma patients & 1366 & - & $>10$ RBC units & $7 / 9$ \\
\hline Borgman et al. (67) & Retrospective & Europe & Trauma patients & 2474 & $\begin{array}{l}\text { High FFP:RBC }>1: 2 \\
\text { Low FFP:RBC }<1: 2\end{array}$ & No difference & $8 / 9$ \\
\hline Brown et al. (36) & Prospective & USA & Trauma patients & 1877 & $\begin{array}{l}\text { Acute traumatic coagulopathy } \\
\text { Non-acute traumatic coagulopathy }\end{array}$ & $\begin{array}{l}\text { Crystalloid, RBC, and FFP } \\
\text { administration }\end{array}$ & $7 / 9$ \\
\hline Innerhofer et al. (68) & Prospective & Europe & Trauma patients & 144 & $\begin{array}{l}\text { Fibrinogen and/or prothrombin } \\
\text { complex concentrate alone } \\
\text { Additionally FFP }\end{array}$ & FFP administration & $8 / 9$ \\
\hline Minei et al. (69) & Prospective & USA & Trauma patients & 916 & $\begin{array}{l}\text { MOF } \\
\text { Non-MOF }\end{array}$ & $\begin{array}{l}\text { FFP administration } \\
\text { Crystalloid administration }\end{array}$ & $9 / 9$ \\
\hline Neal et al. (70) & Prospective & USA & Trauma patients & 452 & Crystalloid:RBC ratio & $\begin{array}{l}\text { Crystalloid: } \mathrm{RBC} \text { ratio } \\
>1.5: 1\end{array}$ & $9 / 9$ \\
\hline Duchesne et al. (71) & Retrospective & USA & Trauma patients & 188 & $\begin{array}{l}\text { Hypertonic solution } \\
\text { Isotonic solution }\end{array}$ & Isotonic solution & $7 / 9$ \\
\hline
\end{tabular}

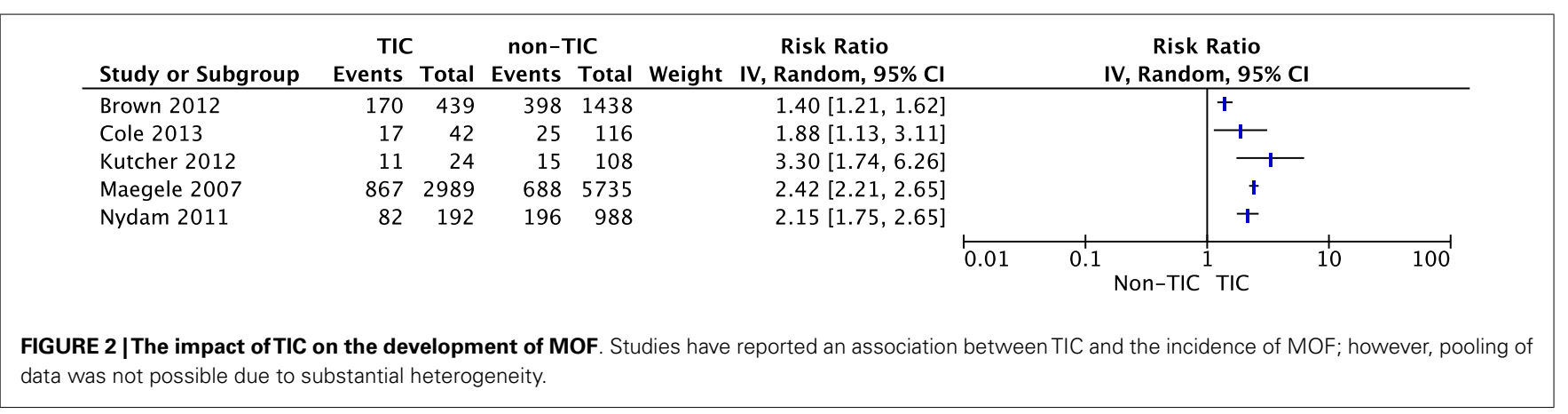


transfused and the incidence of $\operatorname{MOF}(43,49)$. In addition, most studies reported an increased risk for MOF after administration of more than six units; however, studies could not be pooled due to differences in outcomes measures. Besides the amount of RBCs administrated, the age of red blood cells of $>14$ days was found as an independent risk factor in four studies. Storage of RBCs for over 14 days was reported to increase the risk of MOF with an OR of 1.16 (95\% CI $1.02-1.32 ; P=0.03)$. The OR increased to 1.22 (95\% CI $1.06-1.41 ; P=0.006)$ when the RBC units were older than 21 days (45).

Eight studies investigated the effect of FFPs on the development of MOF. Two studies observed a relation between the administration of FFPs and MOF $(57,69)$. Other studies reported merely a trend or results were not adjusted for confounders $(33,36,42,50,52,53)$. When data of five observational studies were pooled for meta-analysis, there was a significant association between a high FFP:RBC ratio of $\geq 1: 1$ and MOF (RR 1.11, 95\% CI 1.04-1.19, Figure 3). Of note, studies were limited in design. The effect of platelets on the development of MOF was investigated in five studies. No significant association between platelet administration and MOF was reported in these studies (52, 53, $57,61,63)$.

\section{Procoagulant agents}

Five studies reported on the relation between MOF and the use of procoagulant agents in patients with severe hemorrhage. In an RCT with 573 patients, recombinant factor VII (rVII) significantly reduced transfusion requirements in both blunt and penetrating trauma patients and showed a trend toward a lower MOF rate in blunt trauma patients (60). Another RCT showed a lower incidence of MOF in patients treated with rVII, although these results were not significant (58). Pooling of data from these two RCTs suggested a lower incidence of MOF in patients treated with rVII compared to placebo (RR 0.81, 95\% CI 0.68-0.98, Figure 4).

The early and high-dose administration of antithrombin (AT) significantly reduced duration of MOF, but did not reduce the incidence of MOF (44). Of note, there was no significant difference in safety profile, including thromboembolic events, between the groups. Two studies reported that prothrombin complex concentrate (PCC) administration resulted in decreased transfusion requirements with an associated significant lower frequency of MOF in severely injured trauma patients $(62,77)$.

In summary, the limitedly available data suggest that procoagulant agents do not contribute to a higher incidence of thromboembolic events and subsequently MOF in severe trauma patients. In fact, these agents are associated with reduced transfusion requirements and a reduced incidence of MOF.

\section{DISCUSSION}

Risk factors for TIC-associated MOF in severely injured trauma patients are early hypocoagulopathy, whereas later in the course after admission, the occurrence of thromboembolic events was associated with MOF. Risk factors for transfusion-associated MOF were the administration of fluids and red blood cell units, the age of red blood cells and an FFP:RBC ratio $\geq 1$ :1. Risk factors are summarized in Table 3.

Hemorrhagic shock and early presence of hypocoagulopathy are risk factors for MOF in trauma patients. Subsequently, after at least 24-h after admission, thromboembolic events were reported as risk factors. Thereby, the coagulation profile associated with MOF seems to change over time. In an effort to reconcile these findings, we hypothesize that patients can transfer

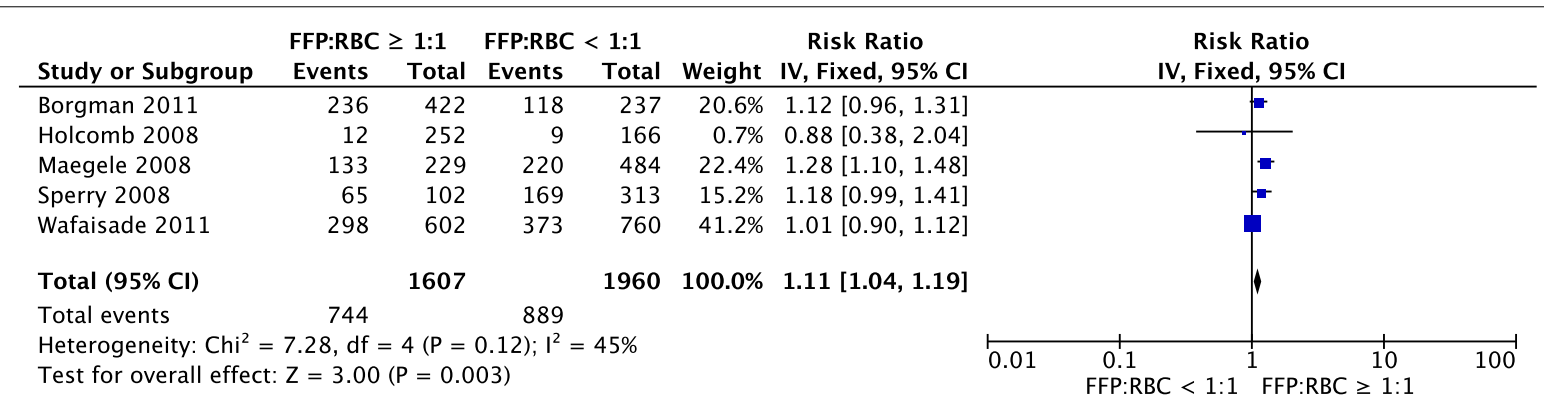

FIGURE 3 | Meta-analysis: the impact of a high FFP:RBC ratio $(\geq 1: 1)$ versus a low FFP:RBC ratio $(<1: 1)$ on the development of MOF. A significant association between a high FFP:RBC ratio and the incidence of MOF is observed $(P=0.003)$.

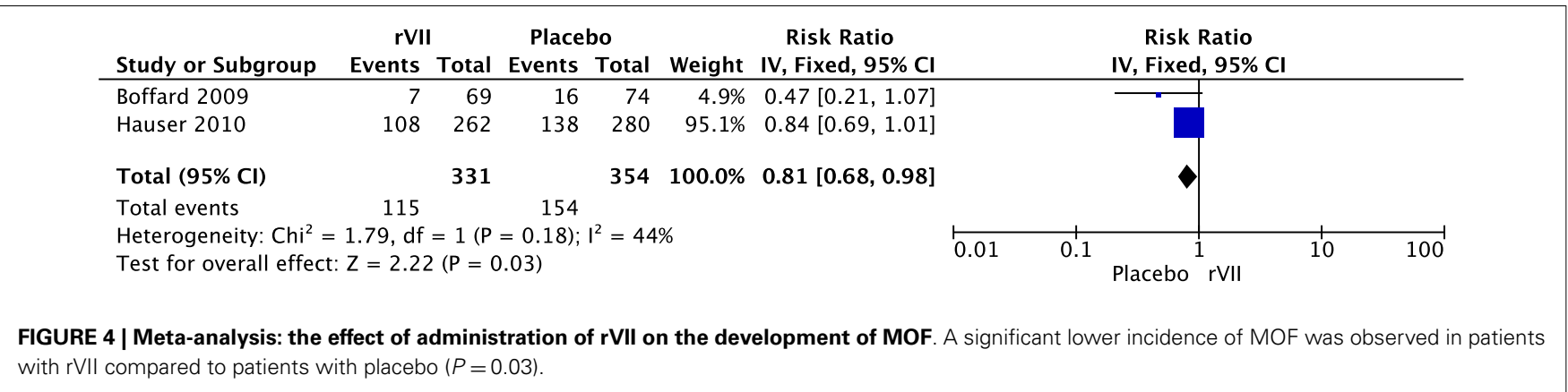


from a hypocoagulable state on admission toward a hypercoagulable state later during the hospital stay, which may predispose to MOF. Immediately after tissue injury, thrombomodulin complexes and extracellular histones activate protein $\mathrm{C}$, which leads to hypocoagulopathy due to the inhibition of FVa and FVII and hyperfibrinolysis $(28,37,74,75)$. Activation of protein $C$ results in utilization of protein $C$. If protein $C$ levels are consumed and patients do not recover their protein $\mathrm{C}$ levels, inhibition of $\mathrm{FVa}$ and VII will not occur, causing a hypercoagulable state. This may be followed by the formation of vascular thrombi leading to cell damage in organs and eventually MOF (Figure 5). Further studies are required to confirm this hypothesis.

Risk factors for transfusion-associated MOF are administration of crystalloids, transfusion of RBCs, the age of RBCs $>14$ days and an FFP:RBC ratio $\geq 1: 1$. When transfusion of fluids and blood products is inevitable a limited amount of fluid and blood products is recommended. We found that a high FFP:RBC ratio is an independent risk factor for MOF. However, since transfusion with a low FFP:RBC ratio of $<1: 1$ is associated with a higher

Table 3 | Risk factors for TIC- and transfusion-associated MOF.

\section{Trauma-induced coagulopathy}

Hypocoagulpathy on emergency department (26, 30, 33, 35-39)

High activated protein $C$ levels on emergency department $(36,38,39)$

High extracellular histones levels on emergency department (37)

Depleted PC levels during hospital stay (38)

Thromboembolic events, e.g., DIC and DVT during hospital stay $(76,78)$

\section{Transfusion strategy}

Transfusion of RBCs, FFPs, and crystalloids within first $24 \mathrm{~h}$ post-injury

$(6,36,41,43,45,65)$

Age $\mathrm{RBC}>2$ weeks (45) mortality due to bleeding $(50,51,79,80)$, clear recommendations on the FFP:RBC ratio, with the aim to limit MOF cannot be made. In particular, due to the different scoring systems used to define MOF in the meta-analysis. Further studies on risks and benefits of blood product ratios are warranted. A possible explanation for the association between the administration of RBCs in trauma patients and MOF may be storage time. However, the use of fresh blood only is probably not feasible in exsanguinating trauma patients. Furthermore, limited data in this study suggest that procoagulant agents do not contribute to a higher incidence of thromboembolic events and subsequently MOF in severely injured trauma patients. In fact, they seem to reduce the risk of MOF, which is most likely related to a decrease in transfusion requirements. Whether the addition of procoagulant agents may decrease transfusion requirements and subsequently the development of MOF remains to be determined.

\section{LIMITATIONS}

There are several limitations to this review. The included studies have a considerable risk of bias related to design and methodology and several studies did not adjust for confounders. Also, there was a relevant heterogeneity as data were presented as mean or median, as frequencies and percentages, and as odds ratios with 95\% confidence intervals. This hampered pooling of data in the meta-analysis. Pooling of data was feasible in 7 out of the 50 included studies. Additionally, we have used the NewcastleOttawa Scale to assess the quality of observational studies. Previous studies reported a low reliability of the scale due to differences in assessment and low agreement between reviewers, which is a limitation of the scale and subsequently of this study $(81,82)$. However, despite these limitations, the Cochrane Collaboration recommends the Newcastle-Ottawa scale as the most useful tool for assessing the risk of bias in non-RCTs (83). Furthermore,

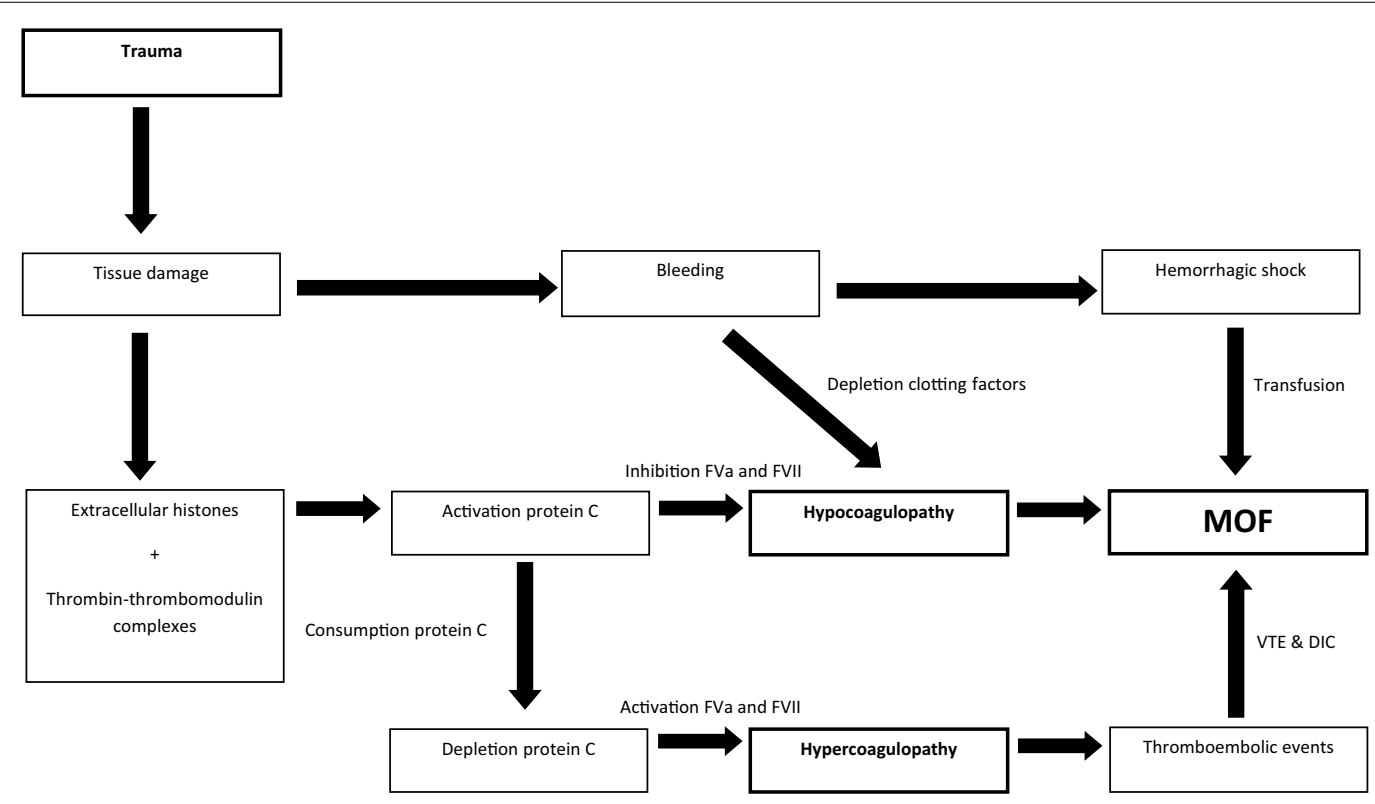

FIGURE 5 | Linking hypo- and hypercoagulopathy in the development of MOF in trauma patients; a hypothesis. 
there is a lack of a uniform definition of MOF. The use of different scores of MOF hampers interpretation of the results of the meta-analyses and therefore no firm conclusions can be drawn. Additional studies are required to confirm the results of this study.

\section{CONCLUSION}

Identifying patients at high risk for MOF may guide the need for monitoring of organ failure and may provide avoidance of therapy, which can aggravate organ failure. Early hypocoagulopathy and shock are risk factors for TIC-associated MOF in severely injured trauma patients. Later in the course of trauma, a hypercoagulable state with the occurrence of thromboembolic events predisposes to MOF. Risk factors for transfusion-associated MOF include the administration of crystalloids and red blood cells and a prolonged storage time of red blood cells. However, pooling of data was hampered by heterogeneity of the study populations and outcome measures. Future prospective studies investigating TIC- and transfusion-associated risk factors on late outcome are required.

\section{SUPPLEMENTARY MATERIAL}

The Supplementary Material for this article can be found online at http://journal.frontiersin.org/article/10.3389/fmed.2015.00024/ abstract

\section{REFERENCES}

1. Sauaia A, Moore FA, Moore EE, Moser KS, Brennan R, Read RA, et al. Epidemiology of trauma deaths: a reassessment. J Trauma (1995) 38(2):185-93. doi:10.1097/00005373-199502000-00006

2. Soreide K, Kruger AJ, Vardal AL, Ellingsen CL, Soreide E, Lossius HM. Epidemiology and contemporary patterns of trauma deaths: changing place, similar pace, older face. World J Surg (2007) 31(11):2092-103. doi:10.1007/s00268-0079226-9

3. Dewar DC, Tarrant SM, King KL, Balogh ZJ. Changes in the epidemiology and prediction of multiple-organ failure after injury. J Trauma Acute Care Surg (2013) 74(3):774-9. doi:10.1097/TA.0b013e31827a6e69

4. Nast-Kolb D, Aufmkolk M, Rucholtz S, Obertacke U, Waydhas C. Multiple organ failure still a major cause of morbidity but not mortality in blunt multiple trauma. J Trauma (2001) 51(5):835-41. doi:10.1097/00005373-20011100000003

5. Brattstrom O, Granath F, Rossi P, Oldner A. Early predictors of morbidity and mortality in trauma patients treated in the intensive care unit. Acta Anaesthesiol Scand (2010) 54(8):1007-17. doi:10.1111/j.1399-6576.2010.02266.x

6. Ciesla DJ, Moore EE, Johnson JL, Burch JM, Cothren CC, Sauaia A. A 12-year prospective study of postinjury multiple organ failure: has anything changed? Arch Surg (2005) 140(5):432-8. doi:10.1001/archsurg.140.5.432

7. Dunn EL, Moore EE, Breslich DJ, Galloway WB. Acidosis-induced coagulopathy. Surg Forum (1979) 30:471-3.

8. Schochl H, Frietsch T, Pavelka M, Jambor C. Hyperfibrinolysis after major trauma: differential diagnosis of lysis patterns and prognostic value of thrombelastometry. J Trauma (2009) 67(1):125-31. doi:10.1097/TA.0b013e31818b2483

9. Johansson PI, Stensballe J, Rasmussen LS, Ostrowski SR. A high admission syndecan-1 level, a marker of endothelial glycocalyx degradation, is associated with inflammation, protein $\mathrm{C}$ depletion, fibrinolysis, and increased mortality in trauma patients. Ann Surg (2011) 254(2):194-200. doi:10.1097/SLA. 0b013e318226113d

10. MacLeod JB, Lynn M, McKenney MG, Cohn SM, Murtha M. Early coagulopathy predicts mortality in trauma. J Trauma (2003) 55(1):39-44. doi:10.1097/01.TA. 0000075338.21177.EF

11. Hess JR, Lindell AL, Stansbury LG, Dutton RP, Scalea TM. The prevalence of abnormal results of conventional coagulation tests on admission to a trauma center. Transfusion (2009) 49(1):34-9. doi:10.1111/j.1537-2995.2008.01944.x

12. Brohi K, Singh J, Heron M, Coats T. Acute traumatic coagulopathy. J Trauma (2003) 54(6):1127-30. doi:10.1097/01.TA.0000069184.82147.06
13. Plotkin AJ, Wade CE, Jenkins DH, Smith KA, Noe JC, Park MS, et al. A reduction in clot formation rate and strength assessed by thrombelastography is indicative of transfusion requirements in patients with penetrating injuries. J Trauma (2008) 64(2 Suppl):S64-8. doi:10.1097/TA.0b013e318160772d

14. del Junco DJ, Holcomb JB, Fox EE, Brasel KJ, Phelan HA, Bulger EM, et al. Resuscitate early with plasma and platelets or balance blood products gradually: findings from the PROMMTT study. J Trauma Acute Care Surg (2013) 75(1 Suppl 1):S24-30. doi:10.1097/TA.0b013e31828fa3b9

15. Brown LM, Aro SO, Cohen MJ, Holcomb JB, Wade CE, Brasel KJ, et al. A high fresh frozen plasma: packed red blood cell transfusion ratio decreases mortality in all massively transfused trauma patients regardless of admission international normalized ratio. J Trauma (2011) 71(2 Suppl 3):S358-63. doi:10.1097/TA.0b013e318227f152

16. Morrison CA, Carrick MM, Norman MA, Scott BG, Welsh FJ, Tsai P, et al. Hypotensive resuscitation strategy reduces transfusion requirements and severe postoperative coagulopathy in trauma patients with hemorrhagic shock: preliminary results of a randomized controlled trial. J Trauma (2011) 70(3):652-63. doi:10.1097/TA.0b013e31820e77ea

17. Moher D, Liberati A, Tetzlaff J, Altman DG. Preferred reporting items for systematic reviews and meta-analyses: the PRISMA statement. BMJ (2009) 339:b2535. doi:10.1136/bmj.b2535

18. Sauaia A, Moore EE, Johnson JL, Ciesla DJ, Biffl WL, Banerjee A. Validation of postinjury multiple organ failure scores. Shock (2009) 31(5):438-47. doi:10.1097/SHK.0b013e31818ba4c6

19. Grotz M, von GM, Stalp M, Kaufmann U, Hildebrand F, Pape HC. [Scoring multiple organ failure after severe trauma. Comparison of the Goris, Marshall and Moore scores]. Chirurg (2001) 72(6):723-30. doi:10.1007/s001040170130

20. Antonelli M, Moreno R, Vincent JL, Sprung CL, Mendoca A, Passariello M, et al. Application of SOFA score to trauma patients. Sequential organ failure assessment. Intensive Care Med (1999) 25(4):389-94. doi:10.1007/s001340050863

21. Wells G, Shea B, O'Connel J. The Newcastle-Ottawa Scale (NOS) for Assessing the Quality of Nonrandomised Studies in Meta-Analysis (2011). Available from: http://www.ohri.ca/programs/clinical_epidemiology/oxford.asp

22. Higgins JPT, Altman DG. Chapter 8: assessing risk of bias in included studies. In: Higgins J, Green S, editors. The Cochrane Collaboration, 5.0.1 ed. Chichester: John Wiley \& Sons, Ltd (2008).

23. Nuytinck JK, Goris JA, Redl H, Schlag G, van Munster PJ. Posttraumatic complications and inflammatory mediators. Arch Surg (1986) 121(8):886-90. doi:10.1001/archsurg.1986.01400080028004

24. Wudel JH, Morris JA Jr, Yates K, Wilson A, Bass SM. Massive transfusion: outcome in blunt trauma patients. J Trauma (1991) 31(1):1-7. doi:10.1097/ 00005373-199101000-00001

25. Sigurdsson GH, Christenson JT, El-Rakshy MB, Sadek S. Intestinal platelet trapping after traumatic and septic shock. An early sign of sepsis and multiorgan failure in critically ill patients? Crit Care Med (1992) 20:458-67. doi:10.1097/00003246-199204000-00005

26. Waydhas C, Nast-Kolb D, Kick M, Zettl R, Wiesholler J, Trupka A, et al. [Operation planning of secondary interventions after polytrauma]. Unfallchirurg (1994) 97(5):244-9.

27. Gando S, Nakanishi Y, Tedo I. Cytokines and plasminogen activator inhibitor1 in posttrauma disseminated intravascular coagulation: relationship to multiple organ dysfunction syndrome. Crit Care Med (1995) 23(11):1835-42. doi:10.1097/00003246-199511000-00009

28. Gando S, Nakanishi Y, Kameue T, Nanzaki S. Soluble thrombomodulin increases in patients with disseminated intravascular coagulation and in those with multiple organ dysfunction syndrome after trauma: role of neutrophil elastase. J Trauma (1995) 39(4):660-4. doi:10.1097/00005373-199510000-00007

29. Sauaia A, Moore FA, Moore EE, Norris JM, Lezotte DC, Hamman RF. Multiple organ failure can be predicted as early as 12 hours after injury. J Trauma (1998) 45(2):291-301. doi:10.1097/00005373-199808000-00014

30. Gando S, Nanzaki S, Kemmotsu O. Disseminated intravascular coagulation and sustained systemic inflammatory response syndrome predict organ dysfunctions after trauma: application of clinical decision analysis. Ann Surg (1999) 229(1):121-7. doi:10.1097/00000658-199901000-00016

31. Raeburn CD, Moore EE, Biffl WL, Johnson JL, Meldrum DR, Offner PJ, et al. The abdominal compartment syndrome is a morbid complication of postinjury damage control surgery. Am J Surg (2001) 182:542-6. doi:10.1016/S00029610(01)00821-2 
32. Newell MA, Bard MR, Goettler CE, Toschlog EA, Schenarts PJ, Sagraves SG, et al. Body mass index and outcomes in critically injured blunt trauma patients: weighing the impact. J Am Coll Surg (2007) 204(5):1056-61. doi:10.1016/j. jamcollsurg.2006.12.042

33. Maegele M, Lefering R, Yucel N, Tjardes T, Rixen D, Paffrath T, et al. Early coagulopathy in multiple injury: an analysis from the German trauma registry on 8724 patients. Injury (2007) 38(3):298-304. doi:10.1016/j.injury.2006.10.003

34. Paffrath T, Wafaisade A, Lefering R, Simanski C, Bouillon B, Spanholtz T, et al. Venous thromboembolism after severe trauma: incidence, risk factors and outcome. Injury (2010) 41(1):97-101. doi:10.1016/j.injury.2009.06.010

35. Nydam TL, Kashuk JL, Moore EE, Johnson JL, Burlew CC, Biffl WL, et al. Refractory postinjury thrombocytopenia is associated with multiple organ failure and adverse outcomes. J Trauma (2011) 70(2):401-6. doi:10.1097/TA. 0b013e31820b5c85

36. Brown JB, Cohen MJ, Minei JP, Maier RV, West MA, Billiar TR, et al. Characterization of acute coagulopathy and sexual dimorphism after injury: females and coagulopathy just do not mix. J Trauma Acute Care Surg (2012) 73(6):1395-400. doi:10.1097/TA.0b013e31825b9f05

37. Kutcher ME, Xu J, Vilardi RF, Ho C, Esmon CT, Cohen MJ. Extracellular histone release in response to traumatic injury: implications for a compensatory role of activated protein C. J Trauma Acute Care Surg (2012) 73(6):1389-94. doi:10.1097/TA.0b013e318270d595

38. Cohen MJ, Call M, Nelson M, Calfee CS, Esmon CT, Brohi K, et al. Critical role of activated protein $\mathrm{C}$ in early coagulopathy and later organ failure, infection and death in trauma patients. Ann Surg (2012) 255(2):379-85. doi:10.1097/SLA.0b013e318235d9e6

39. Cole E, Davenport R, De'Ath H, Manson J, Brockamp T, Brohi K. Coagulation system changes associated with susceptibility to infection in trauma patients. J Trauma Acute Care Surg (2013) 74(1):51-7. doi:10.1097/TA. 0b013e3182788b0f

40. Trentzsch H, Nienaber U, Behnke M, Lefering R, Piltz S. Female sex protects from organ failure and sepsis after major trauma haemorrhage. Injury (2014) 45(Suppl 3):S20-8. doi:10.1016/j.injury.2014.08.013

41. Sauaia A, Moore FA, Moore EE, Haenel JB, Read RA, Lezotte DC. Early predictors of postinjury multiple organ failure. Arch Surg (1994) 129(1):39-45. doi:10.1001/archsurg.1994.01420250051006

42. Lehmann U, Grotz M, Regel G, Rudolph S, Tscherne H. [Does initial management of polytrauma patients have an effect on the development of multiple organ failure? Evaluation of preclinical and clinical data of 1,112 polytrauma patients]. Unfallchirurg (1995) 98(8):442-6.

43. Moore FA, Moore EE, Sauaia A. Blood transfusion. An independent risk factor for postinjury multiple organ failure. Arch Surg (1997) 132(6):620-4. doi:10.1001/archsurg.1997.01430300062013

44. Waydhas C, Nast-Kolb D, Gippner-Steppert C, Trupka A, Pfundstein C, Schweiberer L, et al. High-dose antithrombin III treatment of severely injured patients: results of a prospective study. J Trauma (1998) 45(5):931-40. doi:10. 1097/00005373-199811000-00015

45. Zallen G, Offner PJ, Moore EE, Blackwell J, Ciesla DJ, Gabriel J, et al. Age of transfused blood is an independent risk factor for postinjury multiple organ failure. Am J Surg (1999) 178(6):570-2. doi:10.1016/S0002-9610(99)00239-1

46. Cryer HG, Leong K, McArthur DL, Demetriades D, Bongard FS, Fleming AW, et al. Multiple organ failure: by the time you predict it, it's already there. J Trauma (1999) 46(4):597-604. doi:10.1097/00005373-199904000-00007

47. Frink M, Pape HC, van Griensven M, Krettek C, Chaudry IH, Hildebrand F. Influence of sex and age on mods and cytokines after multiple injuries. Shock (2007) 27:151-6. doi:10.1097/01.shk.0000239767.64786

48. Bulger EM, Cuschieri J, Warner K, Maier RV. Hypertonic resuscitation modulates the inflammatory response in patients with traumatic hemorrhagic shock. Ann Surg (2007) 245(4):635-41. doi:10.1097/01.sla.0000251367.44890.ae

49. Sperry JL, Nathens AB, Frankel HL, Vanek SL, Moore EE, Maier RV, et al. Characterization of the gender dimorphism after injury and hemorrhagic shock: are hormonal differences responsible? Crit Care Med (2008) 36(6):1838-45. doi:10.1097/CCM.0b013e3181760c14

50. Sperry JL, Ochoa JB, Gunn SR, Alarcon LH, Minei JP, Cuschieri J, et al. An FFP:PRBC transfusion ratio $>/=1: 1.5$ is associated with a lower risk of mortality after massive transfusion. J Trauma (2008) 65(5):986-93. doi:10.1097/TA. 0b013e3181878028

51. Maegele M, Lefering R, Paffrath T, Tjardes T, Simanski C, Bouillon B. Red-bloodcell to plasma ratios transfused during massive transfusion are associated with mortality in severe multiple injury: a retrospective analysis from the trauma registry of the Deutsche Gesellschaft fur Unfallchirurgie. Vox Sang (2008) 95(2):112-9. doi:10.1111/j.1423-0410.2008.01074.x

52. Holcomb JB, Wade CE, Michalek JE, Chisholm GB, Zarzabal LA, Schreiber $\mathrm{MA}$, et al. Increased plasma and platelet to red blood cell ratios improves outcome in 466 massively transfused civilian trauma patients. Ann Surg (2008) 248(3):447-58. doi:10.1097/SLA.0b013e318185a9ad

53. Jastrow KM III, Gonzalez EA, McGuire MF, Suliburk JW, Kozar RA, Iyengar $\mathrm{S}$, et al. Early cytokine production risk stratifies trauma patients for multiple organ failure. J Am Coll Surg (2009) 209(3):320-31. doi:10.1016/j.jamcollsurg. 2009.05.002

54. Englehart MS, Cho SD, Morris MS, Gee AC, Riha G, Underwood SJ, et al. Use of leukoreduced blood does not reduce infection, organ failure, or mortality following trauma. World J Surg (2009) 33(8):1626-32. doi:10.1007/s00268-0090076-5

55. Dewar DC, Mackay P, Balogh Z. Epidemiology of post-injury multiple organ failure in an Australian trauma system. ANZ J Surg (2009) 79(6):431-6. doi:10.1111/j.1445-2197.2009.04968.x

56. Mahambrey TD, Fowler RA, Pinto R, Smith TS, Callum JL, Pisani NS, et al. Early massive transfusion in trauma patients: Canadian single-centre retrospective cohort study. Can J Anaesth (2009) 56(10):740-50. doi:10.1007/s12630009-9151-5

57. Watson GA, Sperry JL, Rosengart MR, Minei JP, Harbrecht BG, Moore EE, et al. Fresh frozen plasma is independently associated with a higher risk of multiple organ failure and acute respiratory distress syndrome. J Trauma (2009) 67(2):221-7. doi:10.1097/TA.0b013e3181ad5957

58. Boffard KD, Choong PI, Kluger Y, Riou B, Rizoli SB, Rossaint R, et al. The treatment of bleeding is to stop the bleeding! Treatment of trauma-related hemorrhage. Transfusion (2009) 49(Suppl 5):240S-7S. doi:10.1111/j.1537-2995.2008. 01987.x

59. Cotton BA, Au BK, Nunez TC, Gunter OL, Robertson AM, Young PP. Predefined massive transfusion protocols are associated with a reduction in organ failure and postinjury complications. J Trauma (2009) 66(1):41-8; discussion 48-9. doi:10.1097/TA.0b013e31819313bb

60. Hauser CJ, Boffard K, Dutton R, Bernard GR, Croce MA, Holcomb JB, et al. Results of the CONTROL trial: efficacy and safety of recombinant activated factor VII in the management of refractory traumatic hemorrhage. J Trauma (2010) 69(3):489-500. doi:10.1097/TA.0b013e3181edf36e

61. Johnson JL, Moore EE, Kashuk JL, Banerjee A, Cothren CC, Biffl WL, et al. Effect of blood products transfusion on the development of postinjury multiple organ failure. Arch Surg (2010) 145(10):973-7. doi:10.1001/archsurg.2010.216

62. Nienaber U, Innerhofer P, Westermann I, Schochl H, Attal R, Breitkopf R, et al. The impact of fresh frozen plasma vs coagulation factor concentrates on morbidity and mortality in trauma-associated haemorrhage and massive transfusion. Injury (2011) 42(7):697-701. doi:10.1016/j.injury.2010.12.015

63. Perkins JG, Cap AP, Spinella PC, Shorr AF, Beekley AC, Grathwohl KW, et al. Comparison of platelet transfusion as fresh whole blood versus apheresis platelets for massively transfused combat trauma patients (CME). Transfusion (2011) 51(2):242-52. doi:10.1111/j.1537-2995.2010.02818.x

64. Wafaisade A, Maegele M, Lefering R, Braun M, Peiniger S, Neugebauer E, et al. High plasma to red blood cell ratios are associated with lower mortality rates in patients receiving multiple transfusion $(4 \leq$ red blood cell units $<10)$ during acute trauma resuscitation. J Trauma (2011) 70(1):81-8; discussion 88-9. doi:10.1097/TA.0b013e3182032e0b

65. Hussmann B, Taeger G, Lefering R, Waydhas C, Nast-Kolb D, Ruchholtz S, et al. [Lethality and outcome in multiple injured patients after severe abdominal and pelvic trauma. Influence of preclinical volume replacement - an analysis of 604 patients from the trauma registry of the DGU]. Unfallchirurg (2011) 114(8):705-12. doi:10.1007/s00113-010-1842-4

66. Brakenridge SC, Phelan HA, Henley SS, Golden RM, Kashner TM, Eastman AE, et al. Early blood product and crystalloid volume resuscitation: risk association with multiple organ dysfunction after severe blunt traumatic injury. J Trauma (2011) 71(2):299-305. doi:10.1097/TA.0b013e318224d328

67. Borgman MA, Spinella PC, Holcomb JB, Blackbourne LH, Wade CE, Lefering $\mathrm{R}$, et al. The effect of FFP:RBC ratio on morbidity and mortality in trauma patients based on transfusion prediction score. Vox Sang (2011) 101(1):44-54. doi:10.1111/j.1423-0410.2011.01466.x

68. Innerhofer P, Westermann I, Tauber H, Breitkopf R, Fries D, Kastenberger $\mathrm{T}$, et al. The exclusive use of coagulation factor concentrates enables reversal 
of coagulopathy and decreases transfusion rates in patients with major blunt trauma. Injury (2013) 44:209-16. doi:10.1016/j.injury.2012.08.047

69. Minei JP, Cuschieri J, Sperry J, Moore EE, West MA, Harbrecht BG, et al. The changing pattern and implications of multiple organ failure after blunt injury with hemorrhagic shock. Crit Care Med (2012) 40(4):1129-35. doi:10.1097/ CCM.0b013e3182376e9f

70. Neal MD, Hoffman MK, Cuschieri J, Minei JP, Maier RV, Harbrecht BG, et al. Crystalloid to packed red blood cell transfusion ratio in the massively transfused patient: when a little goes a long way. J Trauma Acute Care Surg (2012) 72(4):892-8. doi:10.1097/TA.0b013e31823d84a7

71. Duchesne JC, Simms E, Guidry C, Duke M, Beeson E, McSwain NE, et al. Damage control immunoregulation: is there a role for low-volume hypertonic saline resuscitation in patients managed with damage control surgery? Am Surg (2012) 78(9):962-8.

72. Pape HC, van GM, Rice J, Gansslen A, Hildebrand F, Zech S, et al. Major secondary surgery in blunt trauma patients and perioperative cytokine liberation: determination of the clinical relevance of biochemical markers. J Trauma (2001) 50(6):989-1000. doi:10.1097/00005373-200106000-00004

73. Frith D, Goslings JC, Gaarder C, Maegele M, Cohen MJ, Allard S, et al. Definition and drivers of acute traumatic coagulopathy: clinical and experimental investigations. J Thromb Haemost (2010) 8(9):1919-25. doi:10.1111/j.1538-7836.2010. 03945.x

74. Floccard B, Rugeri L, Faure A, Saint DM, Boyle EM, Peguet O, et al. Early coagulopathy in trauma patients: an on-scene and hospital admission study. Injury (2012) 43(1):26-32. doi:10.1016/j.injury.2010.11.003

75. Raza I, Davenport R, Rourke C, Platton S, Manson J, Spoors C, et al. The incidence and magnitude of fibrinolytic activation in trauma patients. J Thromb Haemost (2013) 11(2):307-14. doi:10.1111/jth.12078

76. Nielsen VG. A comparison of the thrombelastograph and the ROTEM. Blood Coagul Fibrinolysis (2007) 18(3):247-52. doi:10.1097/MBC.0b013e328092ee05

77. Innerhofer P, Westermann I, Tauber H, Breitkopf R, Fries D, Kastenberger $\mathrm{T}$, et al. The exclusive use of coagulation factor concentrates enables reversal of coagulopathy and decreases transfusion rates in patients with major blunt trauma. Injury (2013) 44(2):209-16. doi:10.1016/j.injury.2012.08.047

78. Tomori T, Hupalo D, Teranishi K, Michaud S, Hammett M, Freilich D, et al. Evaluation of coagulation stages of hemorrhaged swine: comparison of thromboelastography and rotational elastometry. Blood Coagul Fibrinolysis (2010) 21(1):20-7. doi:10.1097/MBC.0b013e32833113e9
79. Zehtabchi S, Nishijima DK. Impact of transfusion of fresh-frozen plasma and packed red blood cells in a 1:1 ratio on survival of emergency department patients with severe trauma. Acad Emerg Med (2009) 16(5):371-8. doi:10.1111/j.1553-2712.2009.00386.x

80. Holcomb JB, Tilley BC, Baraniuk S, Fox EE, Wade CE, Podbielski JM, et al. Transfusion of plasma, platelets, and red blood cells in a 1:1:1 vs a 1:1:2 ratio and mortality in patients with severe trauma: the PROPPR randomized clinical trial. JAMA (2015) 313(5):471-82. doi:10.1001/jama.2015.12

81. Lo CK, Mertz D, Loeb M. Newcastle-Ottawa scale: comparing reviewers' to authors' assessments. BMC Med Res Methodol (2014) 14:45. doi:10.1186/14712288-14-45

82. Hartling L, Milne A, Hamm MP, Vandermeer B, Ansari M, Tsertsvadze A, et al. Testing the Newcastle Ottawa scale showed low reliability between individual reviewers. JClin Epidemiol (2013) 66(9):982-93. doi:10.1016/j.jclinepi.2013. 03.003

83. Higgins JPT, Green S. (editors). Cochrane Handbook for Systematic Reviews of Interventions Version 5.1.0 [Updated March 2011]. The Cochrane Collaboration (2011). Available from: http://www.cochrane-handbook.org

Conflict of Interest Statement: The authors declare that the research was conducted in the absence of any commercial or financial relationships that could be construed as a potential conflict of interest.

Received: 29 January 2015; accepted: 30 March 2015; published online: 24 April 2015. Citation: Balvers K, Wirtz MR, van Dieren S, Goslings JC and Juffermans NP (2015) Risk factors for trauma-induced coagulopathy- and transfusion-associated multiple organ failure in severely injured trauma patients. Front. Med. 2:24. doi: 10.3389/fmed.2015.00024

This article was submitted to Intensive Care Medicine and Anesthesiology, a section of the journal Frontiers in Medicine.

Copyright (C) 2015 Balvers, Wirtz, van Dieren, Goslings and Juffermans. This is an open-access article distributed under the terms of the Creative Commons Attribution License (CC BY). The use, distribution or reproduction in other forums is permitted, provided the original author(s) or licensor are credited and that the original publication in this journal is cited, in accordance with accepted academic practice. No use, distribution or reproduction is permitted which does not comply with these terms. 